ORIGINAL ARTICLE

\title{
Loss of $B C L-2$ in the progression of oral cancer is not attributable to mutations
}

\author{
L L Loro, A C Johannessen, O K Vintermyr
}

J Clin Pathol 2005;58:1157-1162. doi: 10.1136/jicp.2004.021709

See end of article for authors' affiliations

.....................

Correspondence to: Dr L L Loro, Department of Odontology-Oral

Pathology and Forensic Odontology, The Gade Institute, Haukeland University Hospital, N5021 Bergen, Norway; lado.loro@gades.vib.no

Accepted for publication 21 March 2005
Background: $\mathrm{BCL}-2$ and $\mathrm{BAX}$ are important in the regulation of apoptosis. There have been reports of loss of BCL-2 in basal cells of oral epithelial dysplasia (OED) and in oral squamous cell carcinoma (OSCC), and suppression of BAX in poorly differentiated OSCC.

Aim: To investigate whether loss of BCL-2 in OED and OSCC, and of BAX in poorly differentiated OSCC could be attributed to $B C L-2$ and $B A X$ mutations.

Methods: Immunohistochemistry and in situ hybridisation were used to confirm BCL-2 and BAX expression. DNA was extracted from archival samples of OED $(n=22)$ and OSCC $(n=28)$. The connective tissue part from each section was collected separately and used as the normal reference.

Results: No mutations were detected in $B C L-2$ or $B A X$ that could explain their aberrant expression at the mRNA and protein levels in OED and OSCC. The reported A/G polymorphism at codon 7 of $B C L-2$ was detected in 18 of 50 samples and a novel C/T polymorphism at codon 100 was detected in three of 50 samples.

Conclusions: No mutations were found that could explain loss of $\mathrm{BCL}-2$ in oral dysplasia and carcinoma. An unreported C/T polymorphism in BCL-2 was detected. Downregulation of BCL-2 in OED and OSCC may be the result of transcriptional regulation.
○ ral cancer is the 11 th most common cancer globally in terms of numbers. ${ }^{1}$ Oral squamous cell carcinoma (OSCC), the most prevalent type of oral cancer, is often preceded by a premalignant lesion. Histologically, oral premalignant lesions frequently show features of epithelial dysplasia, with moderate and severe epithelial dysplasia carrying the highest risk for malignant transformation. ${ }^{2}$ There are no molecular markers that can predict malignant transformation in potentially malignant oral lesions.

\section{"Aberrant expression of BCL-2 has been reported in} several human cancers, including oral cancer"

The BCL-2 family comprises cell death antagonists, such as BCL-2 and BCL- $\mathrm{X}_{\mathrm{L}}$, and death agonists, such as BAX and BAD. Members of the BCL-2 family have several conserved domains named BCL-2 homology (BH) domains, which participate in the formation of dimers and in the regulation of cell death. ${ }^{3}$ The proapoptotic protein BAX binds to the antiapoptotic protein BCL-2, leading to inactivation of the antiapoptotic function of BCL-2. ${ }^{3}$ BCL-2 inhibits the release of cytochrome $\mathrm{C}$ from the mitochondria through specific mitochondrial channels. ${ }^{4}$ The release of cytochrome C activates apoptotic pathways in cells by its ATP dependent binding to apoptosis protease activating factor $1 .{ }^{5}$ Mutations in the BH4 domain of BCL-2 convert it from an antiapoptotic to a proapoptotic protein. ${ }^{6}$ Frameshift BAX mutations confined to a tract of eight deoxyguanosines $\left(\mathrm{G}_{8}\right)$ (ATG GGG GGG GAG) in the third exon have been reported in over $50 \%$ of human microsatellite mutator phenotype positive colon cancers. ${ }^{7}$ Single nucleotide substitutions resulting in loss of the proapoptotic function of BAX have been reported within the $\mathrm{BHl}$ and $\mathrm{BH} 3$ domains, ${ }^{8}$ and proximal to the $\mathrm{C}$ terminus. ${ }^{9}$

Aberrant expression of BCL-2 has been reported in several human cancers, including oral cancer. ${ }^{10}$ Previously, we reported the loss of BCL-2 in basal cells of oral epithelial dysplasia (OED) and OSCC, and greatly reduced expression of BAX in poorly differentiated OSCC. ${ }^{11}{ }^{12}$ In our present study, we report that loss of BCL-2 in basal cells of OED and OSCC is not attributable to a mutated $B C L-2$ gene. In addition, loss of BAX expression in poorly differentiated OSCC was not related to mutations in BAX. The $\mathrm{A} / \mathrm{G}$ single

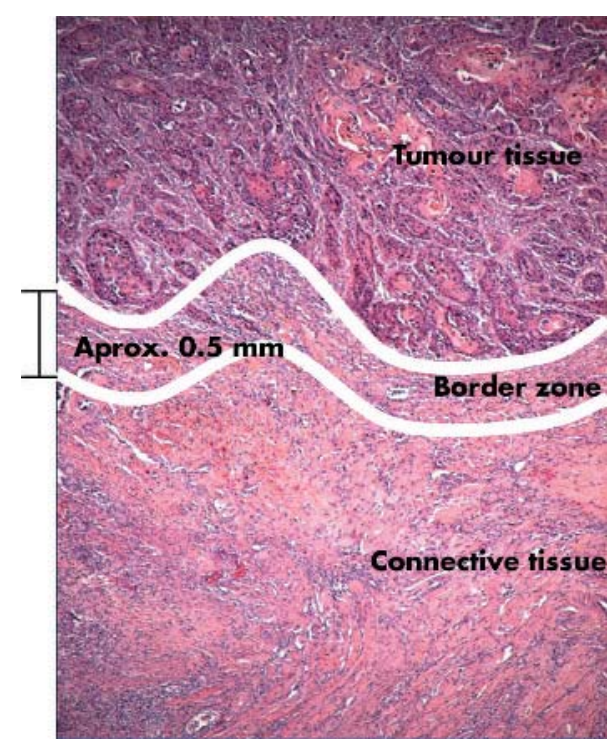

Figure 1 Haematoxylin and eosin section of a well differentiated oral squamous cell carcinoma illustrating the method used for the collection of samples for DNA extraction from the cancerous and connective tissue parts, with an intervening border zone that was not collected.

Abbreviations: $\mathrm{BH}, \mathrm{BCL}-2$ homology; ISH, in situ hybridisation; OED, oral epithelial dysplasia; OSCC, oral squamous cell carcinoma; PCR, polymerase chain reaction; SNP, single nucleotide polymorphism 
nucleotide polymorphism (SNP) at codon 7 of BCL-2 was frequently seen (18 of 50 samples), whereas a novel $\mathrm{C} / \mathrm{T}$ polymorphism at codon 100 was less frequently seen (three of 50 samples) in premalignant and malignant oral epithelia.

\section{MATERIAL AND METHODS \\ Tissue samples}

Formalin fixed, paraffin wax embedded tissue sections of human OED $(\mathrm{n}=22)$ and OSCC $(\mathrm{n}=28)$ were used. The specimens comprised mild $(n=6)$, moderate $(n=7)$, and severe $(\mathrm{n}=9)$ OED, and well differentiated $(\mathrm{n}=19)$, moderately differentiated $(n=6)$, and poorly differentiated $(\mathrm{n}=3)$ OSCC. All the dysplasia and OSCC samples were examined by an experienced pathologist (ACJ) and diagnosed according to the World Health Organisation criteria for the classification of cancer and precancer of the oral mucosa. ${ }^{13}$ Tonsillar tissues were used as controls for BCL-2 and BAX mRNA and protein expression. The connective tissue parts of the dysplasia and OSCC samples were used as non-cancerous control tissues for mutational analysis.

\section{Immunohistochemistry}

Sections ( $5 \mu \mathrm{m}$ thick) were dewaxed in xylene and rehydrated in graded alcohol before pretreatment with $0.1 \%$ protease type xxiv (Sigma, St Louis, Missouri, USA) and microwave treatment, as described previously. ${ }^{12}$ Samples were incubated overnight ( 18 hours) at $4{ }^{\circ} \mathrm{C}$ in a humidified chamber with polyclonal antihuman BCL-2 (1/100 dilution; Pharmingen, San Diego, California, USA) or polyclonal antihuman BAX (1/800 dilution; Santa Cruz Biotechnology, Santa Cruz, California, USA) antibody. The specimens were further processed and the specificity of the anti-BCL-2 antibody tested with recombinant human BCL-2 protein (Pharmingen), as described previously. ${ }^{11}$ Human tonsillar tissues were used as positive controls.

\section{In situ mRNA hybridisation}

Sections ( $5 \mu \mathrm{m}$ thick) of OSCC were processed for the detection of BCL-2 and BAX mRNA by the catalysed signal amplification $^{14}$ method developed for in situ hybridisation (ISH) (Genpoint kit; DakoCytomation, Glostrup, Denmark). The BCL-2 and BAX oligonucleotide probes, the relevant controls, and the ISH protocol have been described previously. ${ }^{12}$ After dewaxing and rehydration, endogenous peroxidase activity was quenched in $0.3 \% \mathrm{H}_{2} \mathrm{O}_{2}$ in $100 \%$ methanol for 20 minutes, followed by microwave treatment. Biotinylated "poly $\mathrm{dT}^{\mathrm{T}}$, sense or antisense BCL-2 and BAX probes were applied to samples at a concentration of $3 \mathrm{ng} / \mu \mathrm{l}$ in mRNA hybridisation solution (DakoCytomation) and hybridised overnight (18 hours) in a humidified chamber.

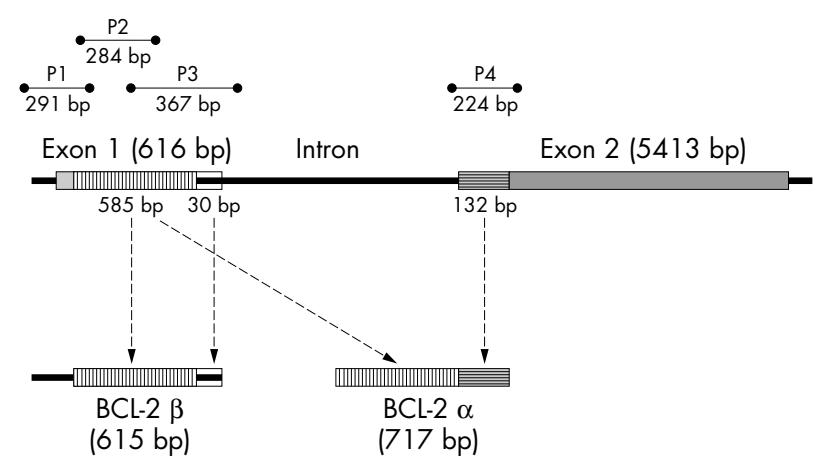

Figure 2 Schematic diagram of the BCL-2 gene, its isoforms, and the polymerase chain reaction oligonucleotide primers used. The primer sets (P1, P2, P3, and P4) were designed to span the coding regions for the $\alpha$ and $\beta$ isoforms of $B C L-2$.
The hybridisation reaction was amplified twice using catalysed signal amplification for ISH (DakoCytomation), visualised with diaminobenzidine chromogen, and counterstained with Mayer's haematoxylin. Positive controls for BCL-2 and BAX mRNA comprised sections of human tonsillar tissue.

\section{DNA isolation}

Paraffin wax embedded OED or OSCC samples placed on uncoated microscopic glass slides were used for the extraction of genomic DNA. Three $10 \mu \mathrm{m}$ sections were macrodissected from each sample. Before DNA extraction, neoplastic or dysplastic epithelium was carefully macrodissected from the surrounding normal stroma (fig 1). The stroma immediately adjacent to the dysplastic or neoplastic epithelium was left as a border zone, whereas the rest of the underlying stroma was collected and used as an internal normal reference. To avoid potential errors caused by the field cancerisation effect, superficial oral epithelium adjacent to OED or OSCC was never included as normal control tissue. For all samples, a haematoxylin and eosin stained section was used to guide tissue macrodissection. Tissues were then digested with proteinase $\mathrm{K}(0.2 \mathrm{mg} / \mathrm{ml})$ in $200 \mu \mathrm{l}$ digestion buffer (50mM Tris/HCl, pH 8.0, ImM EDTA, 0.5\% Tween 20) for 48 hours and DNA isolated using either silica spin columns (Qiagen, Hilden, Germany; QIAamp DNA mini kit and QIAamp DNA blood mini kit handbook. Hilden: Qiagen, 2001) or an automatic DNA extractor (BioRobot M48 workstation; Qiagen; Supplementary protocol: isolation of genomic DNA from paraffin-embedded sections using MAgAttract DNA mini M48 kit. Hilden: Qiagen, 2003), as described by the manufacturer. The quality and quantity of isolated genomic DNA was evaluated by electrophoresis and spectrophotometry (UV-1601; Shimadzu Corp, Kyoto, Japan).

\section{Amplification and sequencing of $B C L-2$ and $B A X$}

Four $B C L-2$ oligonucleotide DNA primers, three of which overlapped (table 1; fig 2), were used for amplification of the coding regions of exons one and two of $B C L-2$. Other than the reverse second primer, ${ }^{15}$ new polymerase chain reaction (PCR) primer pairs ( $\mathrm{Pl}, \mathrm{P} 3$, and $\mathrm{P} 4$ ) were designed using the Oligo Primer Analysis Software (Molecular Biology Insights, Cascade, Colorado, USA). Primers used for amplification and sequencing of the six exons of $B A X$ were as described previously, ${ }^{16}$ except for a new set of laboratory designed primers for amplification and sequencing of exon one (table 1).

For both $B C L-2$ and $B A X$ the PCR amplification reaction mix $(50 \mu \mathrm{l})$ contained $100 \mathrm{ng}$ genomic DNA, $1.875 \mathrm{U}$ Amplitaq Gold polymerase (Applied Biosystems, Warrington, UK), $0.25 \mathrm{mM} \mathrm{dNTP}$, and $0.125 \mu \mathrm{M}$ of each primer in PCR buffer (Applied Biosystems) supplemented with $0.5-2.0 \mathrm{mM} \mathrm{MgCl}_{2}$ (table 1). The PCR reaction was carried out in a GeneAmp PCR system 9700 (Applied Biosystems) for 40 cycles at the appropriate annealing temperature and $\mathrm{MgCl}_{2}$ concentration for each primer set (table 1). Betaine (1.5M; Sigma) was added to the PCR mix for the second set of BCL-2 primers (P2). PCR efficiency was evaluated by electrophoresis in a $3 \%$ agarose gel and visualised by ethidium bromide staining.

PCR products were purified using ExoSAP-IT (USB Corp, Cleveland, Ohio, USA), as described by the manufacturer. The purified PCR products $(2.0-3.5 \mu \mathrm{l})$ were supplemented with $1 \mu$ l BigDye version 1.1 (Applied Biosystems), $1.5 \mu \mathrm{l} 5 \times$ BigDye buffer (Applied Biosystems), and $0.2 \mu \mathrm{M}$ primer and adjusted to $10 \mu \mathrm{l}$ with deoinised $\mathrm{H}_{2} \mathrm{O}$. Direct sequencing of PCR products in the forward and reverse directions was carried out using a capillary automatic sequencer (ABI PRISM 3100 genetic analyser; Applied Biosystems). 


\begin{tabular}{|c|c|c|c|c|c|}
\hline & Forward sequence $\left(5^{\prime}-3^{\prime}\right)$ & Reverse sequence $\left(5^{\prime}-3^{\prime}\right)$ & Product & $\mathrm{T}_{\mathrm{a}}\left(^{\circ} \mathrm{C}\right)$ & $\mathrm{MgCl}_{2}$ \\
\hline \multicolumn{6}{|l|}{$B C L-2$} \\
\hline Exon $1 \mathrm{Pl}$ & cctcgtccaagaatgcaa & gctgggaggagaagat & $291 \mathrm{bp}$ & $56^{\circ} \mathrm{C}$ & $2.0 \mathrm{mM}$ \\
\hline P2 & cgcaccggg catcttctcctcccagc & gagagetcctccaccaccg* & $284 \mathrm{bp}$ & $55^{\circ} \mathrm{C}$ & $0.5 \mathrm{mM}$ \\
\hline P3 & cccggcgacgacttct & agageccacccgcactc & $367 \mathrm{bp}$ & $61.7^{\circ} \mathrm{C}$ & $1.2 \mathrm{mM}$ \\
\hline Exon 2 P4 & cgtggggtggcattctc & gggcaggcatgittgac & $224 \mathrm{bp}$ & $54^{\circ} \mathrm{C}$ & $1.0 \mathrm{mM}$ \\
\hline \multicolumn{6}{|l|}{$B A X$} \\
\hline Exon 1 & cggagcggcggtgatt & aagccccaggecggtag $\dagger$ & $131 \mathrm{bp}$ & $64^{\circ} \mathrm{C}$ & $1.5 \mathrm{mM}$ \\
\hline Exon $2 / 3$ & accctagaacccaagagtc & getgagagtcctgtgtcc & $400 \mathrm{bp}$ & $58^{\circ} \mathrm{C}$ & $1.5 \mathrm{mM}$ \\
\hline Exon $3\left(G_{8}\right)$ tract & atccaggatcgagcagggcg & atcgctcagcttcttggtg & $94 \mathrm{bp}$ & $58^{\circ} \mathrm{C}$ & $1.5 \mathrm{mM}$ \\
\hline Exon 4 & tctcctgcaggatgattgc & tcccaggtcctcacagat & $209 \mathrm{bp}$ & $58^{\circ} \mathrm{C}$ & $1.5 \mathrm{mM}$ \\
\hline Exon 5 & caggcagtggggacaaggtt & gggtggtgggggtgaggag & $129 \mathrm{bp}$ & $60^{\circ} \mathrm{C}$ & $1.5 \mathrm{mM}$ \\
\hline Exon 6 & cccctggecgagtcactgaa & ageccatgteccccaatc & $237 \mathrm{bp}$ & $60^{\circ} \mathrm{C}$ & $1.5 \mathrm{mM}$ \\
\hline \multicolumn{6}{|c|}{$\begin{array}{l}T_{a,} \text { annealing temperature for each primer set. } \\
{ }^{*} A l l l B C L-2 \text { primers were laboratory designed for amplification and sequencing of the } B C L-2 \text { gene in paraffin wax embedded samples except for the second reverse } \\
\text { primer (P2), which was published previously }{ }^{15} ; \text { TPrimers for amplification and sequencing of } B A X \text { were published previously, }{ }^{16} \text { except for the laboratory designed } \\
\text { primers for exon } 1 \text { of } B A X \text {. }\end{array}$} \\
\hline
\end{tabular}

\section{RESULTS}

\section{$B C L-2$ and $B A X$ protein and $m R N A$ expression}

BCL2 expression was low in OSCC samples (fig 3A, B), as we have reported previously. ${ }^{11}$ BAX was widely detected in tumour cells of well differentiated OSCC but in only a few cells in poorly differentiated OSCC (fig 3C, D). In control tonsillar tissue, BCL-2 was predominantly detected in the mantel zones of tonsillar follicles and BAX mainly in the central zones of tonsillar follicles (data not shown).

BCL-2 mRNA was detected in a few cells in the tumour islands of well differentiated OSCC (fig 4A). Strong BCL-2 mRNA reactivity was seen in tumour associated inflammatory cells (fig 4A). Only a few cells were positive for BCL-2 mRNA in poorly differentiated OSCC (fig 4B). BAX mRNA was widely expressed in tumour islands of poorly differentiated OSCC and in tumour related inflammatory cells (fig 4C), but sparse in samples of poorly differentiated OSCC (fig 4D).

In control experiments, the demonstration of mRNA using a "polydT" oligonucleotide probe resulted in positive staining in all cells (data not shown). In positive control tonsillar tissues, BCL-2 was detected mainly in follicular mantel zones (fig 4E) and BAX in the follicular centres (fig 4F). Both BCL-2 and BAX mRNA could also be detected in interfollicular lymphocytes. Incubation with BCL-2 or BAX sense probes or elimination of probes resulted in very low or no reactivity, respectively.

\section{Mutation analyses of $B C L-2$ and $B A X$}

The two exons of $B C L-2$ and six exons of $B A X$ were amplified and sequenced in our study samples. No mutations were detected in sequences encoding both the BCL- $2 \alpha$ and BCL-2 $\beta$ isoforms. The reported A/G SNP at codon $7^{17}$ (http:// www.ncbi.nlm.nih.gov/SNP/snp_ref.cgi?rs $=1801018$ ) was detected in 18 of 50 and an unreported C/T SNP at codon 100 of $B C L-2$ was detected in three of 50 samples in both dysplastic and neoplastic tissues, and corresponding reference samples from underlying stroma (fig 5). Tumour associated genetic alterations have been reported in apparently normal oral epithelium ${ }^{18}$ and in tumour associated stroma of breast carcinomas. ${ }^{19}$ Therefore, to test the level of detection of genetic alterations in tumour associated stroma or contamination of the connective tissue by tumour cells, tumour DNA containing the C/T SNP and DNA from stroma
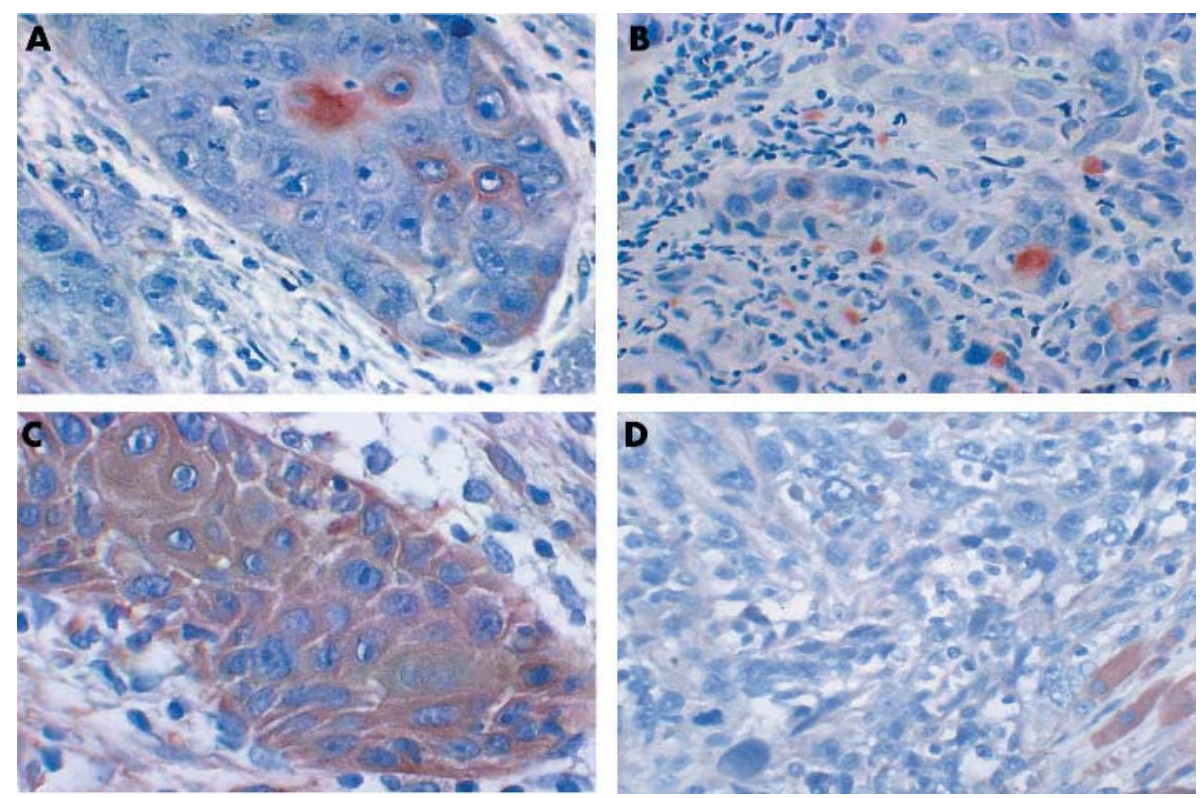

Figure 3 Immunohistochemical staining for BCL-2 in (A) well differentiated and (B) poorly differentiated oral squamous cell carcinoma (OSCC). BAX immunoreactivity in (C) well differentiated and (D) poorly differentiated OSCC. Sections stained with AEC (3-amino-9-ethylcarbazole) and counterstained with Mayer's haematoxylin. 

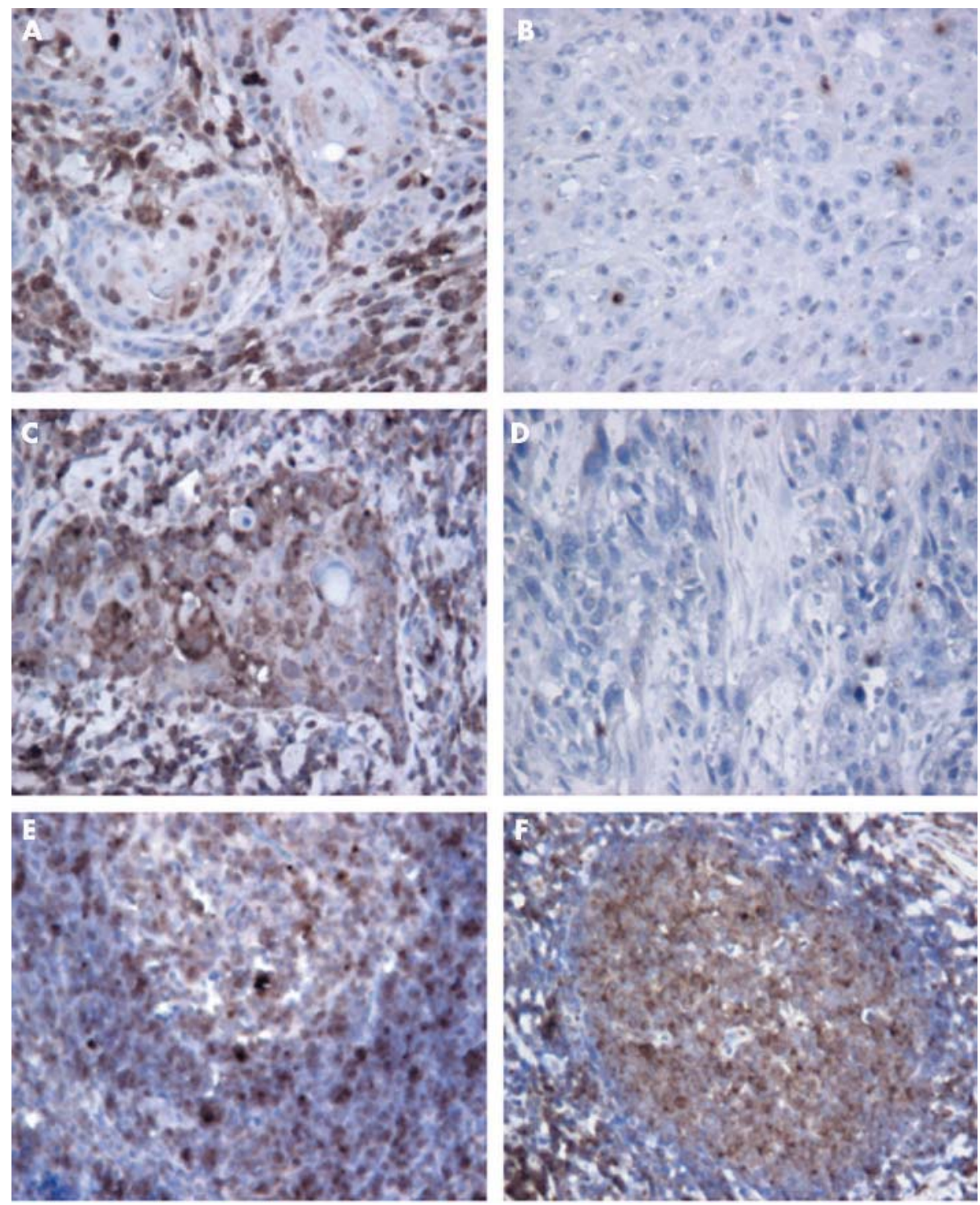

Figure $4 \quad B C L-2 m R N A$ localisation in (A) well differentiated and (B) poorly differentiated oral squamous cell carcinoma (OSCC). BAX $m R N A$ staining in (C) well differentiated and (D) poorly differentiated OSCC. Reactivity for (E) BCL-2 mRNA and (F) BAX mRNA in control tonsillar tissue. BCL-2 and BAX mRNA signals (A-F) were visualised with diaminobenzidine and the sections were counterstained with Mayer's haematoxylin.

without the C/T SNP were serially mixed to produce $50 \%$ (wt/ wt), $12.5 \%$, and $5 \%$ DNA containing the C/T SNP (fig 5A-F). In our hands, the level of detection of the C/T SNP in the mixed DNA was in the order of $5 \%$. In addition, DNA extracted from samples from other sites (skin and pharynx) from patients with the $\mathrm{C} / \mathrm{T}$ SNP also showed the $\mathrm{C} / \mathrm{T}$ polymorphism (fig $5 \mathrm{G}$ ), verifying that this was a germline polymorphism. No mutations in the hot spot eight deoxyguanosine $\left(\mathrm{G}_{8}\right)$ tract in the third exon of $B A X$ were detected in OSCC samples. In a limited number of OSCC samples ( $\mathrm{n}=9$ ), including three poorly differentiated OSCCs, exons one to six of the $B A X$ gene were amplified and sequenced. However, no mutations were detected in these samples. The reported intronic G/A polymorphism, 13 bases downstream of the $3^{\prime}$ end of exon three, was detected in one of nine OSCC samples.

\section{DISCUSSION}

Previously, we showed that BCL-2 mRNA and protein were progressively lost with increasing degree of dysplasia. ${ }^{12}$ In addition, BCL-2 protein was lost in basal cells of well differentiated and poorly differentiated OSCC, whereas BAX was maintained in dysplasia and in well differentiated OSCC, but much reduced in poorly differentiated OSCC. ${ }^{11}{ }^{12}$ Therefore, we wanted to analyse samples of OED and OSCC for mutations that may underlie the loss of BCL-2 in OED and OSCC, and of BAX in poorly differentiated OSCC.

Our mutational analyses based on sequencing of the entire coding regions of the $B C L-2$ and $B A X$ genes indicate that the aberrant expression of $B C L-2$ in OED and OSCC, and of $B A X$ in poorly differentiated OSCC, may not be the result of mutations in these genes. The lack of mutations in these genes suggests that $B C L-2$ in oral premalignant and malignant lesions and BAX in poorly differentiated OSCC may be under transcriptional regulation. There is only one other study on oral cancer that has investigated BCL-2 at both the protein and mRNA levels. Our findings differ from that study, which reported that BCL-2 protein and mRNA are upregulated in OSCC, particularly in poorly differentiated OSCC, and suggested that BCL-2 may be under posttranscriptional regulation because the concentration of BCL-2 protein was much lower than that of the mRNA. ${ }^{20}$ 
A

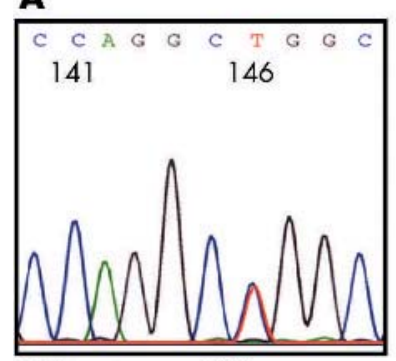

100 ng tumour DNA
B

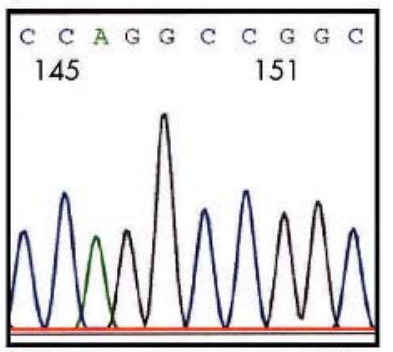

100 ng connective tissue DNA
C

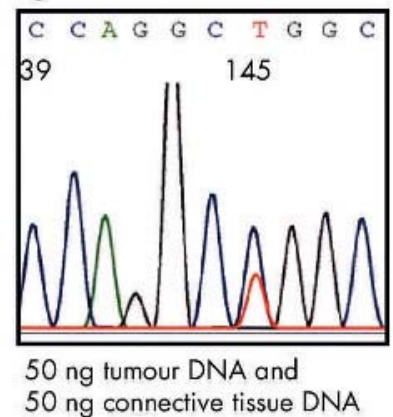

E

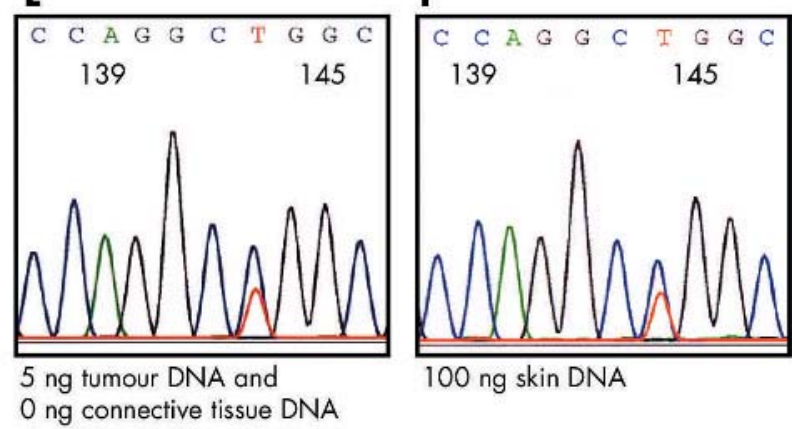

Figure 5 (A) The novel C/T single nucleotide polymorphism (SNP; arrow) at codon 100 of the BCL-2 gene detected in a tumour sample. (B) DNA from the connective tissue of a tumour without the C/T SNP. (C, D) Mixture of tumour DNA with the C/T and connective tissue from the tumour without the C/ T SNP. (E) Detection of the C/T SNP in $5 \mathrm{ng}$ of DNA from the sample shown in (A). (F) DNA from the skin of the same patient as in (A).

The agreement between our immunohistochemical and in situ mRNA hybridisation findings suggests that both BCL-2 and BAX may be under transcriptional regulation in dysplastic and neoplastic oral epithelia.

Several studies have shown that BCL-2 expression is regulated transcriptionally and post-transcriptionally. A wide variety of molecules can downregulate or upregulate $B C L-2$ mRNA or BCL-2 protein including lymphokines, transforming growth factor $\beta$, Epstein Barr virus latent membrane protein 1, p53, retinoids, and phorbol esters. ${ }^{21-26}$ Transcriptional suppression of $B C L-2$ may also result from modulation of the negative response element located at the $5^{\prime}$ untranslated region. ${ }^{26-28}$

\section{"The agreement between our immunohistochemical and in situ mRNA hybridisation findings suggests that both BCL-2 and BAX may be under transcriptional regulation in dysplastic and neoplastic oral epithelia"}

BCL-2 and BCL- $\mathrm{X}_{\mathrm{L}}$ are known to have antiproliferative effects, by delaying progression to $S$ phase from quiescence. ${ }^{29}{ }^{30}$ In addition, the antiproliferative effect of BCL-2 has been shown to inhibit tumour progression in animal tumours. ${ }^{31}{ }^{32}$ Therefore, loss of the suppressive effects of BCL2 may be advantageous for potentially malignant and malignant oral keratinocytes. A suppressive effect of BCL-2 on proliferation is consistent with our earlier study reporting increased proliferative activity (as assessed by Ki-67 labelling) in basal cells of OED and OSCC, which had lost BCL2. ${ }^{123}$ Therefore, loss of BCL-2 in oral keratinocytes may be involved in dysplastic and malignant progression of oral epithelium by making oral keratinocytes more responsive to mitotic stimuli.

The known A/G SNP at codon 7 of $B C L-2^{17}$ (http:// www.ncbi.nlm.nih.gov/SNP/snp_ref.cgi?rs $=1801018$ ) was seen frequently (18 of 50 samples) in our study. A less frequent (three of 50) and unreported C/T polymorphism was detected in oral dysplastic and neoplastic samples. The occurrence of SNPs in the human genome has been associated with susceptibility to many diseases, including cancers. ${ }^{34}$ The observed C/T polymorphism could be a new SNP; however, its low frequency and absence from the SNP databases warrants further validation.

Downregulation of BAX in poorly differentiated OSCC suggests a role for BAX in the development of a more aggressive oral cancer phenotype. Molecular analysis of the conserved eight deoxyguanosines $\left(G_{8}\right)$ tract in exon three and of the other five exons revealed no mutations. Because deregulated BAX expression in poorly differentiated OSCC could not be attributed to mutations in the BAX gene, and because of the concordance of BAX mRNA and protein expression, we suggest that BAX dysregulation in poorly differentiated OSCC may be the result of transcriptional regulation. Transcriptional induction of $B A X$ by $\mathrm{p} 53$ requires a cofactor, the regulation of which is thought to be responsible for the tissue specific expression of BAX and induction of apoptosis. $^{35}$ Myc can also transcritptionally activate BAX expression by binding to a region in the $B A X$ promoter. $^{36}$ Regulation of $B A X$ expression and the interplay between modulating factors is still not well understood.

The molecular biology of oral carcinogenesis is characterised by the activation of oncogenes such as those encoding transforming growth factor $\alpha$, the epidermal growth factor receptor, c-myc/N-myc, cyclin D1, and STAT-3, and inactivation of the tumour suppressor genes p53 and pl6. ${ }^{37}$ Our findings suggest that loss of BCL-2 is an early event during oral carcinogensis and decreased BAX expression seems to be associated with poorly differentiated OSCC. These alterations in BCL-2 and BAX may be involved in dysregulation of apoptosis and contribute to the molecular carcinogenesis of oral cancers. 


\section{Take home messages}

- Loss of BCL-2 in basal cells of potentially malignant and malignant oral epithelia and loss of BAX in poorly differentiated oral squamous cell carcinoma (OSCC) is not associated with mutations in the coding regions of these genes, but may be the result of transcriptional regulation

- These alterations in $\mathrm{BCL}-2$ and $\mathrm{BAX}$ may be involved in dysregulation of apoptosis and contribute to the molecular carcinogenesis of oral cancers

- The aberrant expression of $B C L-2$ and $B A X$ suggests a role, in cooperation with other molecular changes, in the progression of oral dysplasia and oral squamous cell carcinoma

In conclusion, our findings suggest that loss of BCL-2 in basal cells of potentially malignant and malignant oral epithelia and loss of BAX in poorly differentiated OSCC is not associated with mutations in the coding regions of these genes. The aberrant expression of $B C L-2$ and $B A X$ suggests a role, in cooperation with other molecular changes, in the progression of oral dysplasia and oral squamous cell carcinoma.

\section{ACKNOWLEDGEMENTS}

The authors thank Ms G Øijordsbakken and Ms G Fjell for excellent technical assistance.

\section{Authors' affiliations}

L L Loro, A C Johannessen, Department of Odontology-Oral Pathology and Forensic Odontology, Haukeland University Hospital, N5021 Bergen, Norway

O K Vintermyr, Department of Pathology, The Gade Institute, University of Bergen, Haukeland University Hospital

\section{REFERENCES}

1 Stewart BW, Kleihues P. Head and neck cancer. In: Stewart BW, Kleihues P, eds. World cancer report. Lyon: International Agency for Research on Cancer Press, 2003:232-6.

2 Lumerman $\mathbf{H}$, Freedman P, Kerpel S. Oral epithelial dysplasia and the development of invasive squamous cell carcinoma. Oral Surg Oral Med Oral Pathol Oral Radiol Endod 1995;79:321-9.

3 Yin XM, Oltvai ZN, Korsmeyer SJ. BH1 and BH2 domains of $\mathrm{Bcl}-2$ are required for inhibition of apoptosis and heterodimerization with Bax. Nature 1994:369:321-3

4 Yang J, Liu X, Bhalla K, et al. Prevention of apoptosis by Bcl-2: release of cytochrome c from mitochondria blocked. Science 1997; 275:1 129-32.

5 Li P, Nijhawan D, Budihardjo I, et al. Cytochrome c and dATP-dependent formation of Apaf-1/caspase-9 complex initiates an apoptotic protease cascade. Cell 1997;91:479-89

6 Cheng EH, Kirsch DG, Clem RJ, et al. Conversion of Bcl-2 to a Bax-like death effector by caspases. Science 1997;278:1966-8.

7 Rampino $\mathrm{N}$, Yamamoto $\mathrm{H}$, lonov $\mathrm{Y}$, et al. Somatic frameshift mutations in the $B A X$ gene in colon cancers of the microsatellite mutator phenotype. Science 1997;275:967-9

8 Meijerink JP, Mensink EJ, Wang K, et al. Hematopoietic malignancies demonstrate loss-of-function mutations of BAX. Blood 1998;91:2991-7.

9 Gil J, Yamamoto H, Zapata JM, et al. Impairment of the proapoptotic activity of Bax by missense mutations found in gastrointestinal cancers. Cancer Res 1999;59:2034-7.
10 Loro LL, Vintermyr OK, Johannessen AC. Cell death regulation in oral squamous cell carcinoma: methodological considerations and clinical significance. J Oral Pathol Med 2003;32:125-38.

11 Loro LL, Vintermyr OK, Liavaag PG, et al. Oral squamous cell carcinoma is associated with decreased bcl-2/bax expression ratio and increased apoptosis. Hum Pathol 1999;30:1097-105.

12 Loro LL, Johannessen AC, Vintermyr OK. Decreased expression of bcl-2 in moderate and severe oral epithelial dysplasias. Oral Oncol 2002;38:691-8.

13 Pinborg JJ, Reichart PA, Smith CJ, et al. WHO international histological classification of tumours. Histological typing of cancer and precancer of the oral mucosa. Berlin: Springer, 1997.

14 Bobrow MN, Harris TD, Shaughnessy KJ, et al. Catalyzed reporter deposition, a novel method of signal amplification. Application to immunoassays. $J$ Immunol Methods 1989;125:279-85.

15 Tanaka S, Louie DC, Kant JA, et al. Frequent incidence of somatic mutations in translocated BCL2 oncogenes of non-Hodgkin's lymphomas. Blood 1992;79:229-37

16 Chou D, Miyashita T, Mohrenweiser HW, et al. The BAX gene maps to the glioma candidate region at 19q13.3, but is not altered in human gliomas. Cancer Genet Cytogenet 1996;88:136-40.

17 Komaki S, Kohno M, Matsuura N, et al. The polymorphic 43Thr bel-2 protein confers relative resistance to autoimmunity: an analytical evaluation. Hum Genet 1998;103:435-40.

18 Tabor MP, Brakenhoff RH, Ruijter-Schippers HJ, et al. Multiple head and neck tumours frequently originate from a single preneoplastic lesion. Am J Pathol 2002; 161:1051-60

19 Kurose K, Gilley K, Matsumoto S, et al. Frequent somatic mutations in PTEN and TP53 are mutually exclusive in the stroma of breast carcinomas. Nat Genet 2002;32:355-7.

20 Chen Y, Kayano T, Takagi M. Dysregulated expression of bcl-2 and bax in oral carcinomas: evidence of post-transcriptional control. J Oral Pathol Med 2000;29:63-9.

21 Hanada M, Krajewski S, Tanaka S, et al. Regulation of Bcl-2 oncoprotein levels with differentiation of human neuroblastoma cells. Cancer Res 1993;53:4978-86.

22 Henderson S, Rowe M, Gregory C, et al. Induction of bcl-2 expression by Epstein-Barr virus latent membrane protein 1 protects infected $B$ cells from programmed cell death. Cell 1991;65:1107-15.

23 Makover D, Cuddy M, Yum S, et al. Phorbol ester-mediated inhibition of growth and regulation of proto-oncogene expression in the human T cell leukemia line JURKAT. Oncogene 1991;6:455-60.

24 Reed JC. Bcl-2 and the regulation of programmed cell death. J Cell Biol 1994; 124:1-6.

25 Selvakumaran $M$, Lin HK, Sjin RT, et al. The novel primary response gene MyD 118 and the proto-oncogenes myb, myc, and bcl-2 modulate transforming growth factor beta 1-induced apoptosis of myeloid leukemia cells. Mol Cell Biol 1994; 14:2352-60.

26 Miyashita T, Harigai $M$, Hanada $M$, et al. Identification of a p53-dependent negative response element in the bcl-2 gene. Cancer Res 1994;54:3131-5.

27 Young RL, Korsmeyer SJ. A negative regulatory element in the bcl-2 5' untranslated region inhibits expression from an upstream promoter. Mol Cell Biol 1993;13:3686-97.

28 Korner I, Weber-Nordt R, Pfaff P, et al. Analysis of a regulatory element in the 5 '-untranslated region of the bcl-2 gene. FEBS Lett 1997;406:31-2.

29 Greider C, Chattopadhyay A, Parkhurst C, et al. BCL-x(L) and BCL2 delay Myc-induced cell cycle entry through elevation of p27 and inhibition of G1 cyclin-dependent kinases. Oncogene 2002:21:7765-75.

30 Huang DC, O'Reilly LA, Strasser A, et al. The anti-apoptosis function of Bcl-2 can be genetically separated from its inhibitory effect on cell cycle entry. EMBO J 1997; 16:4628-38.

31 Furth PA, Bar-Peled U, Li M, et al. Loss of anti-mitotic effects of $\mathrm{Bcl}-2$ with retention of anti-apoptotic activity during tumor progression in a mouse model. Oncogene 1999; 18:6589-96.

32 Murphy KL, Kittrell FS, Gay JP, et al. Bcl-2 expression delays mammary tumor development in dimethylbenz(a)anthracene-treated transgenic mice. Oncogene 1999; 18:6597-604.

33 Loro LL, Vintermyr OK, Ibrahim SO, et al. Apoptosis and expression of Bax and $\mathrm{Bcl}-2$ in snuff- and non-snuff associated oral squamous cell carcinomas. Anticancer Res 2000;20:2855-60.

34 Erichsen $\mathrm{HC}$, Chanock SJ. SNPs in cancer research and treatment. $\mathrm{Br} J$ Cancer 2004;90:747-51.

35 Thornborrow EC, Manfredi JJ. The tumor suppressor protein p53 requires a cofactor to activate transcriptionally the human BAX promoter. J Biol Chem $2001 ; 276: 15598-608$.

36 Mitchell KO, Ricci MS, Miyashita T, et al. Bax is a transcriptional target and mediator of c-myc-induced apoptosis. Cancer Res 2000;60:6318-25.

37 Nagpal JK, Das BR. Oral cancer: reviewing the present understanding of its molecular mechanism and exploring the future directions for its effective management. Oral Oncol 2003;39:213-21. 